American Journal of Biochemistry and Biotechnology 6 (2): 84-88, 2010

ISSN 1553-3468

(C) 2010 Science Publications

\title{
Apoptosis of human Breast Cancer Cells induced by Ethylacetate Extracts of Propolis
}

\author{
${ }^{1}$ Syamsudin, ${ }^{2}$ Partomuan Simanjuntak, ${ }^{3}$ Ratna Djamil and ${ }^{4}$ Wan Lelly Heffen \\ ${ }^{1}$ Department of Pharmacology, Faculty of Pharmacy, Pancasila University, \\ Jl. Srengseng Sawah, Jagakarsa, Indonesia \\ ${ }^{2}$ Department of Natural Product Chemistry, Research Centre for Biotechnology, \\ Indonesian Institute of Science, Jln. Raya Bogor Km 46, Cibinong 16911, Indonesia \\ ${ }^{3}$ Department of Research and Development, Dharmais Cancer Hospital, \\ Jl. Letjen. S. Parman. Kav 84-86, Jakarta, Indonesia \\ ${ }^{4}$ Department of Biological Pharmacy, Faculty of Pharmacy, Pancasila University, \\ Jl. Srengseng Sawah, Jagakarsa, Indonesia
}

\begin{abstract}
Problem statement: Propolis has been ethno medically claimed to possess a wide array of biological activities including anticancer activity. The purpose of this research was to verify the folklore claim. Approach: This study was performed in a human breast carcinoma cell, MCF-7. Extract of propolis from different solvent, ethylacetate and n-buthanol showed induced apoptotic cells was detected by flow cytometry. Results: The results demonstrated that ethylacetate extract of propolis can induce apoptosis in MCF-7 as large as 13.21\% during the $24 \mathrm{~h}$ incubation. On the other hand, doxorubicin is able to induce apoptosis as large as $18.89 \%$ during the $24 \mathrm{~h}$ incubation. Conclusion: The extracts of propolis ethylacetate had cytotoxic activity and triggers apoptosis on MCF-7 cells.
\end{abstract}

Key words: Apoptosis, propolis, human breast cancer cell

\section{INTRODUCTION}

Apoptosis is cellular suicide or programmed cell death which is mediated by activation of an evolutionary conserved intracellular pathway. Recently the relation of apoptosis and cancer has been emphasized and increasing evidence suggests that the processes of neoplastic transformation, progression and metastasis involve alterations of normal apoptotic pathway (Bold et al., 1997). Apoptotic also gives some clues about effective anticancer therapy and many chemotherapeutic agents were reported to event their anti-tumor effect including apoptosis of cancer cells.

Propolis (bee glue) is a natural resinous product of honey bees. The cancer inhibitory effects of phenolic compounds in propolis have been confirmed on a variety of culture cell lines and animal tumor models (Aso et al., 2004; Scheller et al., 1989). Epidemiological and preclinical evidence suggest that phenolic and polyphenolic photochemical in propolis possess cancer chemo preventive properties (Kwon et al., 2007; Tsao et al., 2004; Orsolic et al., 2005). This has led to an increased emphasis on cancer prevention strategies in which propolis is used as dietary supplement as the richest source of plant phenolics and polyphenolics). The chemical composition of propolis varies according to the plants that can be found in as pecific regions (Ghisalberti, 1979). Although numerous researches have been reported the biological activities of propolis collected in Europe, Brazil and Egypt, information about Indonesian propolis are still limited. Previous study previous study shows that the methanol extracs of propolis from Batang (Central Java) has selectivity on breast cancer cells, MCF-7 and T47D compared to other cancer cells. The objective of this study is to evaluate the ant proliferative effect of propolis and the mechanism of apoptosis in MCF-7 human breast cancer.

\section{MATERIALS AND METHODS}

Sample collection: Propolis samples were collected from Batang (Central Java, one of province of Indonesia). Hand collected propolis samples were kept dessicated in the dark up to their processing.

Corresponding Author: Syamsudin, Department of Pharmacology, Faculty of Pharmacy, Pancasila University, Jl. Srengseng Sawah, Jagakarsa, Indonesia 
Sample extraction: Four hundred gram of each sample was cut into small pieces and extracted at room temperature with $1 \mathrm{Lt}$ of $70 \%$ ethanol (twice after $24 \mathrm{~h}$ ). The ethanolic extracts was evaporated under vacuum at $50^{\circ} \mathrm{C}$ until dryness. The extracts was fractionated using the mixture of ethylacetat and water (1:1) inside a separating funnel. Later, the ethyl acetate layer was separated from water layer. The water layer was refractionated using n-buthanol inside a separating funnel. The n-buthanol layer was separated from the water layer. The ethylacetate, n-buthanol and water phases were concentrated in a vacum evaporated and dried until the weights were stable.

Morphological studies of MCF-7 cells: Morphological studies by using the normal inverted microscope out in order to observe the morphological changes of cell death in MCF-7 cells ellicited by the ethylacetate and n-buthanol extracts. The concentration of the $\mathrm{IC}_{50}$ value of the respective extracts of propolis was used for the morphological studies.

Cell culture and assay for cytotoxic activity: The human breast cancer, MCF-7 cell lines were supplied by Cancer Hospital Center Dharmais, Jakarta, Indonesia. The human tumor cytotoxicities were determined following protocols established by the NCI (Monks et al., 1991). Cellular viability in the presence and absence of experimental agents was determined using the standard 3-(4,5-dimethylthiazol-2-yl)-2,5dimethyltetrazolium bromide (MTT, Sigma, St. Louis, MO) exponentially growing cells were harvested and a 50-iL suspension containing 2500 cells was plated in 96-well microtiter plates (Falcon, Becton Dickinson, $\mathrm{NJ}$ ). After $24 \mathrm{~h}$ of incubation at $37^{\circ} \mathrm{C}$ under $5 \% \mathrm{CO}_{2}$ to allow cell attachment, the cells were treated with varying concentrations of test specimens in their respective medium (100 iL) and incubated for 4 days under the same conditions as above. After adding a solution of MTT for $4 \mathrm{~h}$, the amount of formazan formed was measured spectrophotometrically at $590 \mathrm{~nm}$ using Immuno Mini NJ-2300 plate reader. The inhibition Concentration, $\mathrm{IC}_{50}$ which is the drug concentration that inhibits $50 \%$ of cell lines growth, was determined from the graph. The experiment was conducted in triplicates.

Annexin/propidium iodide-staining: The number of apoptotic cell death induced by ethylacetate and nbuthanol extracts of propolis was measured by flow cytometry. The treated and untreated MCF-7 cells were harvested and washed with cold PBS. An aliquot $\left(10^{5}\right.$ cells/100 $\mu \mathrm{L}$ ) of cell suspension was added with $1 \mu \mathrm{L}$
Fluorescein Isothiocyanate (FITC)-conjugated annexin-V and $2.5 \mu \mathrm{L}$ Propidium Iodide (PI; $250 \mu \mathrm{g} \mathrm{mL}^{-1}$ ). After 10 min incubation on ice, the cells were measured immediately.

Data analysis: All data are presented as mean \pm SD. The mean values were calculated from obtained by no less than three independent experiments.

\section{RESULTS}

Prior to measurement of cytotoxic effects of different extracts of propolis to MCF-7 cells, we analyzed the pattern of MCF-7 cell growth. Since the cells were exponentially growing during 5 days. MCF-7 cells were incubated for $48 \mathrm{~h}$ after treatment with ethylacetate, n-buthanol and aqueous extracts of propolis or doxorubicin. Following appropriate incubation live cells were analyzed by MTT assay. The effect of the propolis extracts on the growth of MCF-7 cells is shown in Fig. 1, where the ethylacetate-extractinduced-MCF-7 cells growth depended on the doses. The $\mathrm{IC}_{50}$ value of the ethylacetate extract is stronger than those of n-buthanol and water extracts, having $\mathrm{IC}_{50}$ $>200 \mu \mathrm{mL}^{-1}$ (Fig. 1).

According to the results of cytotoxicity measurements $\mathrm{IC}_{50}$ of ethyl acetate extract of propolis was $47.45 \mu \mathrm{g} \mathrm{mL}{ }^{-1}$. The occurrence of morphological change of the treated cells indicated the cytotoxicity effect of the fraction Fig. 1. To understand the effect of the fraction on growth inhibition and apoptosis induction, the proliferation kinetic and apoptosis assay were carried out at inhibitory.

Many chemical compounds can inhibit the growth of tumor cells, but not all of them can trigger apoptosis. To determine whether apoptosis was induced by the compounds mentioned above, we performed flow cytometric analysis with Annexin V-FITC conjugated to Propidium Iodide (PI).

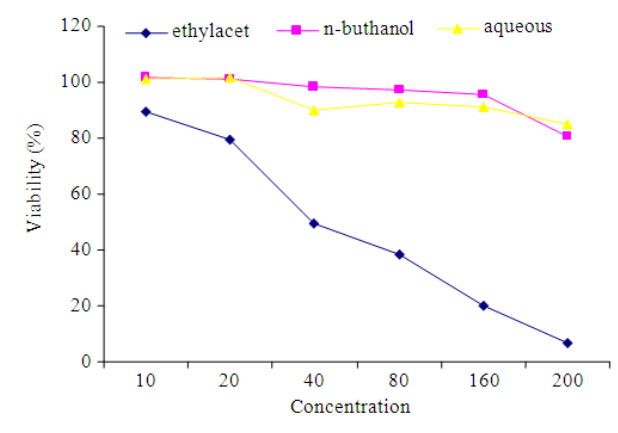

Fig. 1: Effect of propolis extract on the survival rate of MCF-7 cells 


\section{DISCUSSION}

Natural products play an important role in chemotherapy, having contributed considerably to approximately 60 available cancer chemotherapeutic drugs. The need to develop more effective anti-tumor drugs has prompted investigators to explore new sources of pharmacologically active compounds, especially form propolis. Propolis (bee glue) is a natural resinous product of honey bees. The cancer inhibitory effects of phenolic compounds in propolis have been confirmed on a variety of culture cell lines and animal tumor models (Chen et al., 2003; Suzuki et al., 2002). Epidemiological and preclinical evidence suggest that phenolic and polyphenolic phytochemicals in propolis possess cancer chemo preventive properties (Nada et al., 2007). This has led to an increased emphasis on cancer prevention strategies in which propolis is used as dietary supplement as the richest source of plant phenolics and polyphenolics.

Apoptosis also seems to be a reliable marker for the evaluation of potential agents for cancer prevention. A wide variety of natural compounds appear to possess significant cytotoxic as well as chemo preventive activity. Flowcytometry was used to evaluate the behaviour of cells treated with apoptotic agents. Annexin V-FITC-positive, PI-negative (Annexin V-FITC (+) PI $(-)$ ) cells were considered to be in an early apoptotic stage, while Annexin V-FITC-positive, PI-positive (Annexin V-FITC $(+)$ PI $(+)$ ) cells were considered to be late apoptotic or necrotic (Fig. 2). The Fig. 3 shows that the ethyl acetate extract of propolis at the concentration of $47.45 \mu \mathrm{g} \mathrm{mL} \mathrm{m}^{-1}$ can induce apoptosis on MCF-7 cells as large as $13.21 \%$ using flow cytometry method, whereas the doxorubicin at the concentration of $145.57 \mathrm{nM}$ is able to induce apoptosis as large as $18.89 \%$ during the $24 \mathrm{~h}$ incubation. The morphological changes observed using the normal inverted microscope show characteristic rounding off of dying cells on treatment at $\mathrm{IC}_{50}$ concentration with EEP and doxorubicin for $24 \mathrm{~h}$ compared to untreated control (Fig. 4).

The major active components of propolis are flavonoids and phenolic acids present in EEP, they have many biological and pharmacological activities including immunopotentiation and antitumor effects. Phytochemical screenings reveal that moderate concentration of flavonoids, saponins, terpenes and steroids some of which chemical compounds have been associated to cytotoxic activities. This reveals moderate concentration of flavonoids, saponins, terpenes and steroids some of which chemical compounds have been associated to cytotoxic activities. The study by Li et al.
(2007) showed that propolis inhibits cellular proliferation and induces apoptosis in prostate cancer cells. The flavonoids and phenolic components found in propolis are known to affect the apoptosis of prostate cancer cells and may play an important role in cancer chemoprevention (Bankova, 2005).

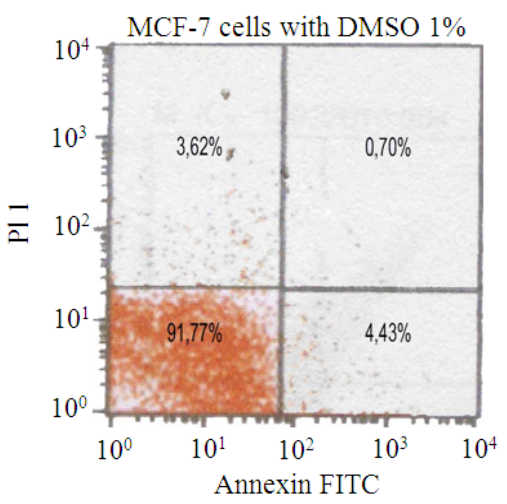

(a)

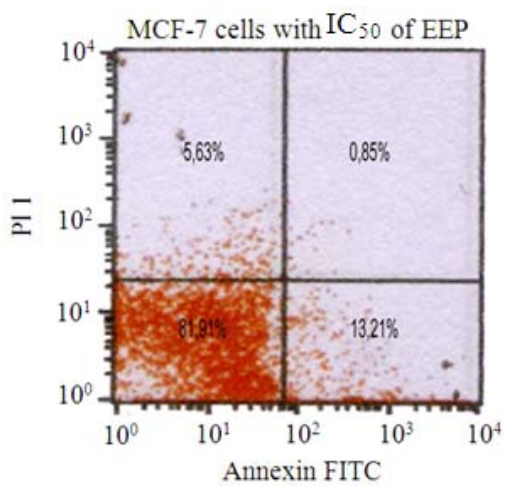

(b)

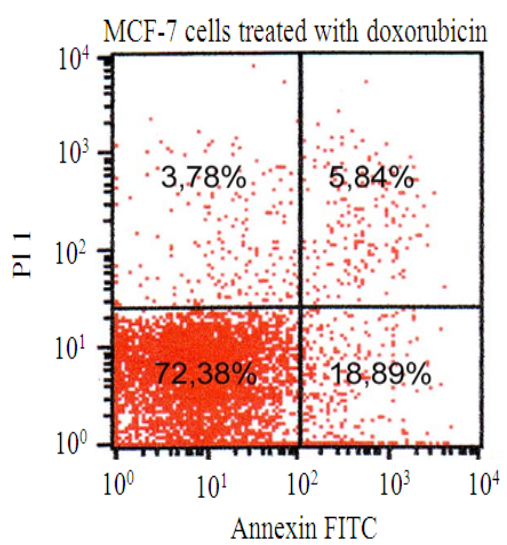

(c)

Fig. 2: Ethylacetate Extract of Propolis (EEP) induction of apoptosis of MCF-7 cells demonstrated by annexin $\mathrm{V}$ staining 
Am. J. Biochem. \& Biotech., 6 (2): 84-88, 2010

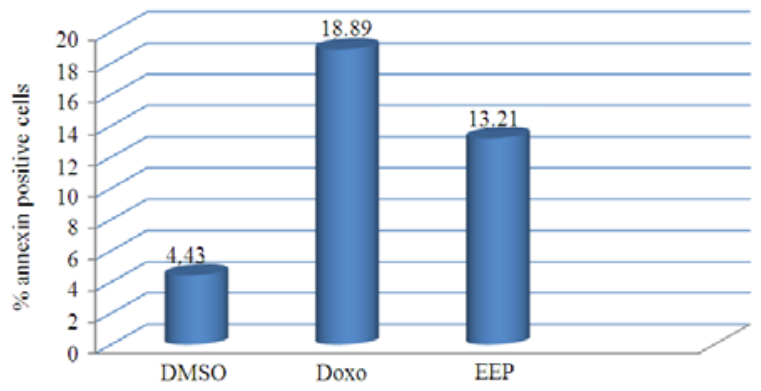

Fig. 3: MCF-7 cells were treated with DMSO, doxorubicin, EEP with $\mathrm{IC}_{50}$ of EP for $24 \mathrm{~h}$, apoptotic cells were demonstrated by determining the number of annexin $\mathrm{V}$ positive cells

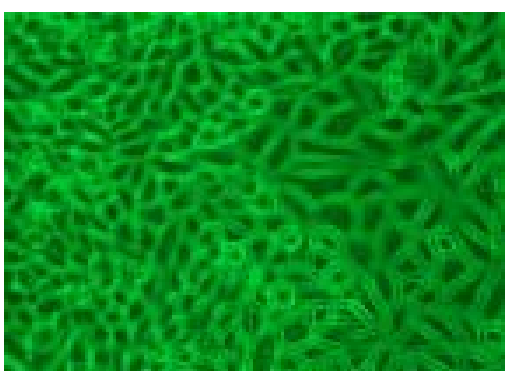

(a)

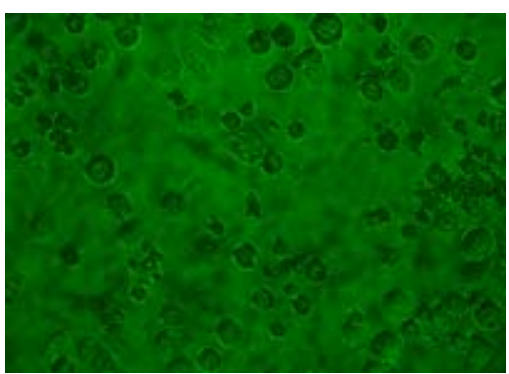

(b)

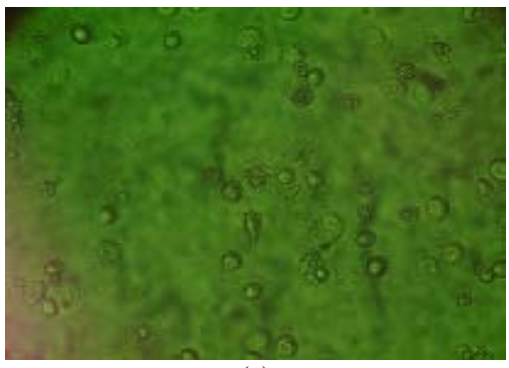

(c)

Fig.4: (A) Morphological features of MCF-7 (B) The changes observed after $24 \mathrm{~h}$ treatment at $\mathrm{IC}_{50}$ concentration with EEP (C) The changes observed after $24 \mathrm{~h}$ treatment at $\mathrm{IC}_{50}$ concentration with Dox (100 x magnification)
This research shows the potential of the ethyl acetate extract of propolis as an anticancer agent to inhibit cell proliferation and trigger apoptosis. Even though the EEP cytotoxic activity is lower than that of conventional chemotherapy agent such as doxorubicin, the EEP IC 50 value is quite promising to be developed as a chemoprevention agen if we consider that this research used MCF-7 known to have high resistance to several chemotherapy agents. MCF-7 cells have low sensitivity against doxorubicin with $\mathrm{IC}_{50} 148 \mathrm{nM}$. The resistance of MCF-7 against doxorubicin is due to the increase of Pgp expression which pumps doxorubicin out of cells. This also happens in other cancer cells (Patel and Tannock, 2009).

\section{CONCLUSION}

The ethylacetate extract of propolis shows sufficiently strong cytotoxicity on MCF-7, with the IC50 $47.45 \mu \mathrm{g} \mathrm{mL}{ }^{-1}$ and triggers apoptosis of MCF-7 cells.

\section{ACKNOWLEDGMENT}

This study was supported by the Research Grant of the Program Hibah Kompetisi (Program of Found Competition) 2009, Directorate of General of Higher Education, Department of National Education, Republic of Indonesia.

\section{REFERENCES}

Aso, K., S. Kanno, T. Tadano, S. Satoh and M. Ishikawa, 2004. Inhibitory effect of propolis on the growth of human leukemia U937. Biol. Pharm. Bull., 27: 727-730. DOI: 10.1248/bpb.27.1555

Bankova, V., 2005. Chemical diversity of propolis and the problem of standardization. J. Ethnopharm. 100: 114-117. DOI: 10.1016. J.Jep.2005.05.004

Bold, R.J., P.M. Temuhlen, D.J. McConkey, 1997. Apoptosis, cancer and cancer therapy. Surg. Oncol., 6: 113-142.

Chen, C., W. Chia-Li, H. Shing and J. Lin, 2003. Cytotoxic prenylflavanones from taiwanese propolis. J. Nat. Prod., 66: 503-506. DOI: 10.1021/np0203180

Ghisalberti, E.L., 1979. Propolis: A review. Bee World, 60: 59-84.

Kwon, K.H., A. Barve, S. Yu, M. Huang and A.T. Kong, 2007. Cancer chemoprevention by phytochemicals: Potencial molecular targets, biomarkers and animal models. Acta Pharmacol. Sin., 28: 1409-1421. DOI: $10.1111 /$ j.1745.7254.2005 
Li, H., A. Kapur, J.X. Yang, S., Srivastava, D.G. McLeod and J.F. Paredes Guzman et al., 2007. Antiproliferation of human prostate cancer cells by ethanolic extracts of Brazilian propolis and its botanical origin. Int. J. Oncol., 31:601-606. PMID: 17671687

Monks, A.D., P. Scudeiro, R. Skehan, Shoemaker and K. Paul et al., 1991. Feasibility of high-flux anticancer drug screen using a diverse panel of cultured human tumor cell lines. J. Natl. Cancer Inst., 83: 757-766. DOI: 10.1093/jnci/83.11.738

Nada, O., V. Benkovi, A. Horvat-Kne, N. Kopjar, I. Kosalec and M. Bakmaz et al., 2007. Assessment by survival analysis of the radioprotective properties of propolis and its polyphenolic compounds. Biol. Pharm. Bull., 30: 946-951. DOI: 10.1248/bpb.30.946

Orsolic, N., L. Sver, S. Terzic and J. Basic, 2005. Peroral application of Water-Soluble Derivate of Propolis (WSPD) and its related polyphenolic compounds and their influence on immunological and antitumor activity. Vet. Res. Commun., 29: 575-593. DOI: $10.1023 / 4$
Patel, J.K. and I.A. Tannock, 2009. The influence of Pglycoprotein expression and its inhibitors on the distribution of doxorubicin in breast tumors. BMC Cancer, 9: 356. DOI: 10.1186/1471-2407-9-356

Scheller, S., W. Krol, J. Swiacik, S. Owczarek, J. Gabrys and J. Shani, 1989. Antitumoral property of Ethanolic Extract of Propolis (EEP) in micebearing Ehrlich carcinoma. Z. Naturforsch., 44C: 1063-1065.

Suzuki, I., I. Hyashi, T. Takaki, D. Groverman and Y. Fujimiya, 2002. Antitumor and anticytopenic effects of aqueous extracts of propolis in combination with chemotherapeutic agents. Cancer Biother. Radiopharm., 17: 553-562. DOI: 10.1089/108497802760804781

Tsao, A.S., E.S. Kim and W.K. Hong, 2004. Chemoprevention of cancer. CA Cancer J. Clin., 54: 150-180. DOI: 10.3322/canjcln.54.3.15.1004 